\title{
Статистика у цифрову епоху: наукові здобутки професіоналів і початківців
}

Життєдіяльність сучасного суспільства важко уявити без цифрових комп'ютерних технологій. Можливості всесвітньої мережі Інтернету давно вже вийшли за межі інформаційно-комунікативного простору. Сьогодні цифрові технології забезпечують функціонування різноманітних сфер суспільного життя - від виробничих процесів, фінансово-банківських і торговельних операцій до надання різноманітних соціальних послуг: адміністративних, освітніх, медичних, юридичних тощо. Утім шлях у глобальний світ взаємоузгоджених великих масивів даних з їх обробкою, узагальненням, зберіганням та аналізом неможливо пройти без застосування інформаційних технологій та статистики.

Про сучасні виклики статистиці та відповіді на запити національної і міжнародної цифрової економіки йшлося на дослідницькій секції “Статистика XXI століття: нові виклики, нові можливості”, що проводилася кафедрою статистики та демографії економічного факультету Київського національного університету імені Тараса Шевченка у рамках Міжнародного економічного форуму EFBM'2019 "Економіка. Фінанси. Бізнес. Управління. Глобальні економічні виклики та можливості у цифрову епоху" (21-24 травня 2019 року). Знаково, що Форум EFBM'2019 започатковано економічним факультетом, який цього року святкував 75-ий рік свого народження і разом з усім колективом університету відзначав його ювілейну 185-ту річницю.

У роботі дослідницької секції взяли участь 24 провідні вітчизняні та іноземні вчені та практики у галузі економіки, статистики, економічної кібернетики, клінічної аналітики та демографії (7 докторів наук, з них 5 професорів, 1 старший науковий співробітник, 1 керівник міжнародної компанії; 12 кандидатів наук, а також 5 наукових співробітників, аспіранти та магістрант). Серед учасників конференції - науковці з закладів вищої освіти України, Грузії (Батумський державний університет імені Шота Руставелі), Польщі (Центр регіональної статистики, Познанський університет економіки та бізнесу). Українську наукову спільноту представляли вчені та викладачі закладів трьох регіонів України: Києва (Київський національний університет імені Тараса Шевченка, ДВНЗ “Ки- ївський національний економічний університет імені Вадима Гетьмана”, Національна академія статистики, обліку та аудиту Державної служби статистики України, Київський національний торговельно-економічний університет, Національний медичний університет імені О. О. Богомольця, Iнститут демографії та соціальних досліджень імені М. В. Птухи НАН України, ДУ “Інститут економіки та прогнозування НАН України”), Білоцерківського аграрного університету, Центральноукраїнського державного педагогічного університету імені Володимира Винниченка (м. Кривий Ріг), а також науковці - представники компанії Chiltern Clinical Research Ukraine LLC.

На секції обговорювалися проблеми сучасного інформаційно-аналітичного і методологічного забезпечення статистичного оцінювання й моделювання соціально-економічних і демографічних процесів в умовах втілення державних реформ у різних сферах суспільного життя та запровадження міжнародних статистичних стандартів. Дискутувалися актуальні питання розширення можливостей цифрової економіки у сфері урядування, інвестування, розвитку муніципальної інфраструктури, зовнішньої торгівлі, а також у рамках реалізації Україною Програми ООН "Цілі сталого розвитку” (продовольча безпека і подолання бідності, забезпечення якісної освіти упродовж життя, поліпшення здоров'я матерів тощо).

3 привітальним словом до учасників форуму і дослідницької секції звернулася декан економічного факультету Київського національного університету імені Тараса Шевченка, доктор економічних наук, професор А. Ігнатюк. Вона наголосила, що особливістю статистики в епоху цифрової економіки є якісна обробка та аналіз великих масивів даних для швидкого прийняття ефективних управлінських рішень в умовах конкуренції та інформатизації суспільства.

Модератор дослідницької секції - в. о. завідувача кафедри статистики та демографії економічного факультету, кандидат економічних наук, доцент I. Гончар зазначив, що в умовах розвитку ринкової економіки та подальшої євроінтеграції завдання статистики полягає не лише у задоволенні інформаційних потреб. Пріоритетним напрямом стає інформаційна підтримка прийняття

(С) 3. О. Пальян, 2019 
виважених рішень в усіх сферах діяльності. Розширюються аналітичні можливості статистичної інформації, розробляються моделі короткострокових і довгострокових прогнозів з акцентом на оцінюванні їх ефективності. Гармонізується з міжнародними стандартами національна система статистичних показників.

У рамках дослідницької секції розгорнулися три панельні дискусії:

1) макроекономічні виклики статистиці - обговорювалися проблеми інформаційного і методологічного забезпечення статистичного аналізу макроекономічних явищ, зокрема оцінювання рівня продовольчої безпеки і доступності раціонального продуктового кошика для населення, а також рівня збалансованості зовнішньої торгівлі товарами. Відбувся обмін результатами міжнародної і національної практик оцінювання статистичного потенціалу, інформаційно-аналітичних аспектів пенсійного забезпечення;

2) демографія та соціальна економіка, спікер якої - заступник директора з наукової роботи Інституту демографії та соціальних досліджень імені М. В.Птухи НАН України, доктор економічних наук, старший науковий співробітник, член-кореспондент НАН України О. Гладун ознайомив учасників із колективною розробкою методології визначення демографічних втрат унаслідок соціальних катастроф, наголосивши на проблемі адекватного інформаційного забезпечення в умовах зміни адміністративно-територіальних меж України та міграційної рухливості населення. Обговорювалися методологічні питання побудови реальних реконструйованих і змодельованих гіпотетичних балансів населення України, а також непрямого оцінювання чисельності осіб з інвалідністю за даними перепису населення Польщі. Жвава дискусія відбулася стосовно теоретичних і практичних аспектів побудови демографічних прогнозів та прогнозування виживаності частини материнського покоління з виявленою онкологічною патологією. До дискусії приєднались учасники інших дослідницьких секцій - науковці закладів вищої освіти України та Казахстану. У контексті діджиталізації соціальних послуг обговорювалися питання ефективності запровадження електронних систем у сфері охорони здоров'я;

3) бізнес-аналітика: зміна концептуальних підходів - доповідалися й активно обговорювались актуальні питання використання сучасних цифрових технологій у віртуальному інвестуванні за допомогою криптовалют і можливостей статистичного оцінювання співвідношення ризик-дохідність у процесі інвестування у різні криптовалюти. У рамках упровадження національної реформи у сфері місцевого самоврядування, боротьби з корупцією і залучення громадськості та бізнесу до публічних дискусій і прийняття управлінських рішень розглядалися питання статистичного вимірювання рівня електронного урядування країн світу та підвищення місця України у глобальному рейтингу е-урядування. Обговорювалися проблеми впровадження інформаційно-комунікаційних технологій у транспортну інфраструктуру, розробки статистичних індикаторів та критеріїв статистичного оцінювання розвитку громадського транспорту у невеликих містах України, а також розробки різноваріантних моделей удосконалення муніципальних транспортних послуг.

Окремим дискусійним питанням було забезпечення якості вищої статистичної освіти відповідно до потреб бізнесу та запитів цифрової економіки. Зокрема, обговорювалися роль прикладної статистики у формуванні сучасного рівня обліково-аналітичної освіти, перспективні напрями підготовки статистиків у вищій школі, необхідність розробки освітніх бізнес-моделей, а також методологічні питання статистичного оцінювання ефективності навчання на масових відкритих онлайн курсах. Усі ці питання зачіпали інтереси присутніх на дослідницькій секції студентів спеціальностей "Економічна аналітика та статистика", "Бізнесстатистика", "Прикладна статистика”, які у живій співбесіді охоче ставили запитання, висловлювали свої думки та цікаві пропозиції.

За результатами роботи дослідницької секції прийнято рішення рекомендувати Державній службі статистики України у співпраці з науковцями і практиками розробити інформаційне й методичне забезпечення оцінювання ефективності впровадження державних реформ в економічній сфері, системах місцевого самоврядування, пенсійного забезпечення, охорони здоров'я та освіти.

Розробка та втілення у життя актуальних наукових проєктів неможливі без належного кадрового потенціалу. Тому дуже важливо не лише підтримувати високий науковий рівень зрілих професіоналів, а і готувати нову генерацію майбутніх науковців, здатних оцінювати ризики й наслідки соціально-економічної політики, визначати іï пріоритети та шляхи реалізації. У цьому контексті варта згадати про ще одну важливу подію, яка відбулася 25-26 квітня 2019 року, - II тур Всеукраїнського конкурсу студентських наукових робіт 3 галузей знань і спеціальностей за спеціалізацією “Економічна аналітика та статистика". Примітно, що після довгої перерви відродження конкурсу зі статистики відбулося саме на економічному факультеті Київського національного університету імені Тараса Шевченка.

Студенти різних спеціальностей та різних курсів навчання підготували і надіслали цікаві й змістовні наукові роботи. Галузева конкурсна комісія II туру конкурсу, до складу якої входили 9 знаних вчених і провідних викладачів із шести закладів вищої освіти, розглянула 36 студентських 
наукових робіт, що надійшли з 22-х 3ВО України. Рецензування кожної роботи проводилося двома незалежними членами комісії за 100-бальною шкалою із виведенням середнього бала та рейтингуванням студентських наукових робіт. У ході обговорення підсумків рецензування галузевою конкурсною комісією визначено претендентами на перемогу у конкурсі та запрошено до участі у підсумковій науково-практичній конференції авторів студентських робіт, що посіли з першого по дев’яте місця в рейтингу. За результатами доповідей, презентацій та участі у дискусії студентські наукові роботи були нагороджені дипломами різного ступеня, а саме: дипломом I ступеня - дві роботи (Львівський національний університет імені Івана Франка, Київський національний університет імені Тараса Шевченка); дипломом II ступеня - дві роботи (Київський національний університет імені Тараса Шевченка, Полтавська державна аграрна академія); дипломом III ступеня - чотири роботи (Житомирський національний агроекологічний університет, ДВНЗ “Київський національний економічний університет імені Вадима Гетьмана”, Київський національний університет імені Тараса Шевченка, Харківський національний автомобільно-дорожній університет).

Кожен студент - учасник підсумкової науково-практичної конференції був відзначений заохочувальними грамотами в одній із номінацій, а саме, за: кращу наукову роботу, активну участь у науко- вій дискусії, практичну спрямованість наукової роботи, а також за оригінальну презентацію.

Підсумкова науково-практична конференція дала кожному учасникові шанс проявити свою креативність і захистити результати наукового дослідження в рамках дискусії та обміну думками. Це була чудова нагода поринути у творчу атмосферу однодумців, оцінити власні досягнення на загальному фоні та визначитись у подальшій науково-дослідницькій роботі.

У рамках проведення II туру Всеукраїнського конкурсу студентських наукових робіт з галузей знань і спеціальностей за спеціалізацією "Економічна аналітика та статистика” кафедрою статистики та демографії КНУ імені Тараса Шевченка було проведено круглий стіл на тему “Сучасна освітня бізнес-модель вищої школи: проблеми та шляхи забезпечення конкурентності”. У засіданні взяли участь завідувачі кафедр статистики закладів вищої освіти України, професори, провідні науковці та практики. На круглий стіл був запрошений начальник відділу модернізації вищої освіти ДНУ “Інститут модернізації змісту освіти” МОН України, доктор економічних наук, профеcop К. Шапошников, який підтримав пропозиції колег і запропонував реальні шляхи співпраці в інноваційних впровадженнях у вищу освіту, а також окреслив дієві способи залучення обдарованої молоді до науково-прикладних досліджень, участі у міжнародних і національних наукових програмах. 